\title{
特集 まちづくりにおける都市計画，建築規制の権限行使のあり方一規制 権者の裁量拡大論と規制基準明記論【コラム】
}

\section{裁量拡大論に潜む問題点}

The Risk on Theory of Expanding Administrative Discretion in Building Regulatory Law

Yoko SEKI : Attorney at law

「周辺の景観と調和させること」など，抽象的 な言葉で表現される文言によって規制を施し，個 別具体的な事案に応じた柔軟な法解釈を可能とし， 行政裁量を拡大させるべきだという考え方がある。 抽象的な文言は, 法改正を待たずして臨機応変な 対応を可能にすることから，まちづくりの観点か らは好ましいといえるだろう。

また，いわゆる明確性の原則は，刑事法や表現 の自由に対する規制法などの場面で要求される原 理であって, 建築の世界で厳格に要求されている わけではない。

しかしながら，抽象的な定めによって行政裁量 を拡大させようという考え方は難しい問題を孕ん でいる。なぜなら, 法令において漠然とした表現 を用いることを認めると，行政庁の恣意を招き， 法解釈の安定性や平等性に疑義が生じる可能性が あるからである。

具体例で説明しょう。Aと Bの 2 つの似たよう な建築計画があり，その周辺の環境も似たり寄っ たりであるものの, A は周辺の環境と調和してい るものとされたにもかかわらず， B は周辺の環境 と調和していないとされるという不合理な事態も， 行政の裁量が広い場合には生じ易くなる。

また，ある人が一定規模の建物を建築したいと 思い, それが可能であると行政の空口で事前に確 認したうえで，土地を購入したとする。その後，
関葉子*

計画に反対する周辺住民が行政にプレッシャーを かけた結果, 行政の解釈が変わり, 当該計画は周囲 の景観と調和していないものとされ，規模の縮小 を余儀なくされるといった事態も生じ得るだろう。 あるいは，行政庁からは周辺の環境と調和してい るものとして建築が認められ工事を進めたものの, 事後的に争訟で周辺の環境と調和していないもの として許可等が取り消されてしまうといった事態 も生じ易い。いずれもまちづくりを重視する立場 からは好ましいという意見があるかもしれないが， 法治主義が骨抜きにされるおそれがある。

以上のとおり, 抽象的な法令の定めをおいて行政 裁量を拡大し，美しいまちづくりを実現するとい う考え方は, 法治主義や国民の予測可能性などと の関係では少なからぬ問題を孕んでいる。

なお, 現行法では, 建築関係で漠然とした法令 の定めを置いたからといって直ちに行政の裁量が 拡大するとは限らない。なぜなら, 行政手続法は, 申請に対する処分に関し審査基準を定めるものと し, 審査基準は許認可等の性質に照らしてできる 限り具体的なものとしなければならず，特別の支 障があるときを除きそれを公にすることを求めて いるからである (同法 5 条)。その趣旨は, 行政 の恣意を排除し, 公平な法解釈適用を実現する点 にある。各自治体の定める開発許可の基準などが その例である。 